\title{
First report of the L1014F $k d r$ mutation in wild populations of Anopheles arabiensis in Cabo Verde, West Africa
}

Derciliano Lopes da Cruz ${ }^{1}$, Marcelo Henrique Santos Paiva ${ }^{1,2^{*}} \mathbb{D}$, Duschinka Ribeiro Duarte Guedes ${ }^{1}$, Elainne Christine de Souza Gomes ${ }^{3}$, Silvia Gonçalves Pires ${ }^{4}$, Lara Ferrero Gomez ${ }^{4}$ and Constância Flávia Junqueira Ayres ${ }^{1}$

\begin{abstract}
Background: Due to the lack of vaccines, malaria control mainly involves the control of anopheline vectors (Anopheles spp.) using chemical insecticides. However, the prolonged and indiscriminate use of these compounds has led to the emergence of resistance in Anopheles populations in Africa. Insecticide resistance surveillance programs are less frequent in Cabo Verde than in other African countries. This study aimed to investigate the circulation of the L1014F and L1014S alleles in natural populations of Anopheles arabiensis collected from two sampling sites in the city of Praia, Cabo Verde.

Methods: Anopheles larvae were collected from the two sampling sites and reared in the laboratory until the adult stage. Mosquitoes were first morphologically identified by classical taxonomy and then by molecular species identification using molecular markers. All Anopheles arabiensis were subjected to PCR analysis to screen for mutations associated to resistance in the $\mathrm{Na}_{v}$ gene.

Results: A total of 105 mosquitoes, all belonging to the Anopheles gambiae complex, were identified by classical taxonomy as well as by molecular taxonomy. Molecular identification showed that 100\% of the An. gambiae senso lato specimens analyzed corresponded to An. arabiensis. Analysis of the $\mathrm{Na}_{v}$ gene revealed the presence of $\mathrm{L} 1014 \mathrm{~S}$ and L1014F alleles with frequencies of 0.10 and 0.19 , respectively.

Conclusions: Our data demonstrated, for the first time, the presence of the L1014F allele in the An. arabiensis population from Cabo Verde, as well as an increase in the frequency of the kdr L1014S allele reported in a previous study. The results of this study demonstrate the need to establish new approaches in vector control programs in Cabo Verde.
\end{abstract}

Keywords: Malaria, Anopheles arabiensis, Knockdown resistance, Kdr mutation

\footnotetext{
${ }^{*}$ Correspondence: marcelo.paiva@ufpe.br

${ }^{2}$ Centro Academico do Agreste, Universidade Federal de Pernambuco, Rodovia BR-104, km 59-Nova Caruaru, Caruaru, PE 55002-970, Brazil

Full list of author information is available at the end of the article
} permits use, sharing, adaptation, distribution and reproduction in any medium or format, as long as you give appropriate credit to the original author(s) and the source, provide a link to the Creative Commons licence, and indicate if changes were made. The images or other third party material in this article are included in the article's Creative Commons licence, unless indicated otherwise in a credit line to the material. If material is not included in the article's Creative Commons licence and your intended use is not permitted by statutory regulation or exceeds the permitted use, you will need to obtain permission directly from the copyright holder. To view a copy of this licence, visit http://creativecommons.org/licenses/by/4.0/. The Creative Commons Public Domain Dedication waiver (http://creativeco mmons.org/publicdomain/zero/1.0/) applies to the data made available in this article, unless otherwise stated in a credit line to the data. 


\section{Graphical Abstract}

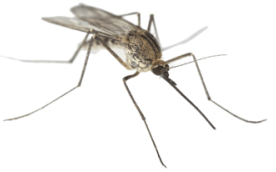

Mosquito Colection

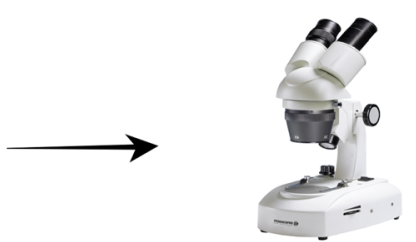

Classical taxonomy

\section{Experimental}

design

Screened mutations

$$
\begin{aligned}
& \text { L1014F and } \\
& \text { L1014S }
\end{aligned}
$$

Sequence analysis

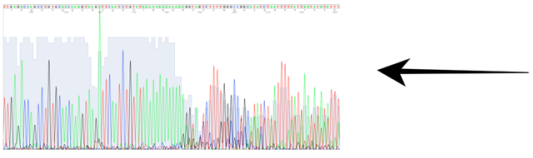

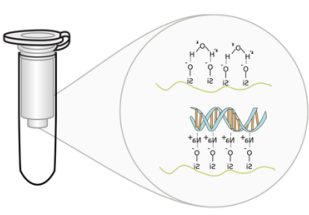

DNA extraction

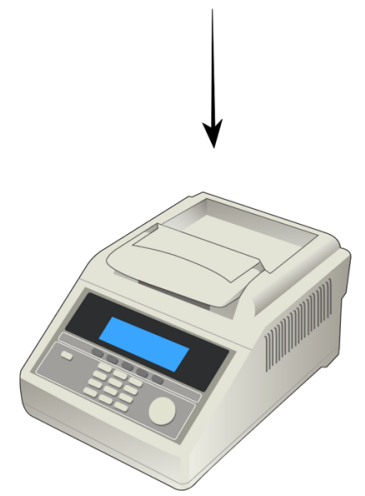

Molecular taxonomy and $k d r$ genotyping
Malaria, caused by Plasmodium spp., is considered to be one of the most important vector-borne diseases from a global perspective. These parasites are transmitted by anopheline mosquitos (Anopheles spp.), and the highest world incidence is found in the African continent [1], where Plasmodium spp. are mainly transmitted by mosquitoes of the Anopheles gambiae complex [2-4]. Currently, this complex consists of at least seven cryptic species [5, 6], of which the most efficient are Anopheles gambiae sensu stricto (s.s.) and An. arabiensis [7-9]. In Cabo Verde, an archipelago located in the eastern Atlantic Ocean, off the coast of West Africa, the only species from this complex associated with disease transmission is An. arabiensis [10-14]. Malaria is considered to be endemic in the archipelago, although transmission has varied over the years. However, in the last 3 consecutive years there has been no local transmission in Cabo Verde; consequently, the archipelago is eligible to apply for the World Health Organization (WHO) certification of malaria elimination [15].

Malaria prevention relies mostly on vector control interventions based on the use of chemical approaches, such as long-lasting insecticidal nets (LLINs) and indoor residual spraying (IRS) $[16,17]$. In Cabo Verde, since 1999, the vector control program has included the use of IRS with deltamethrin (an insecticide of the pyrethroid class) to control adult mosquitoes [18].

The extensive and indiscriminate use of chemical compounds has resulted in the emergence of a wide range of resistance in wild Anopheles populations, mainly in African countries [19]. Two mechanisms have been reported underlying resistance to xenobiotics in these populations: target-site insensitivity and metabolic resistance [20, 21]. Both mechanisms have already been documented in $A n$. arabiensis in West Africa [22]. Target-site insensitivity in Anopheles is caused mainly by mutations present in the voltage-gated sodium channel $\left(N a_{v}\right)$ (domains II-IV) and they are commonly known as knockdown resistance $(k d r)$ mutations. This particular mechanism has been reported in several studies conducted throughout the African continent [23]. $K d r$ mutations are among the best characterized point mutations and are often associated with resistance to pyrethroid (PYR) and organochlorine (OC) insecticides [24]. Two $k d r$ mutations have been detected in the $N a_{v}$ gene (at position 1014 of the encoded protein) of Anopheles populations: the replacement of leucine by phenylalanine (L1014F), found mainly in West Africa (the " $k d r$-west"), and the replacement of leucine by serine (L1014S), found mainly in East Africa (the " $k d r$ east") [20, 25-27]. These mutations have been frequently detected in mosquitoes from African countries [28-33] 
and they have been used as a molecular marker for PYR resistance in Anopheles populations [34-36].

Information on the molecular mechanisms underlying resistance to xenobiotics in Anopheles populations is limited in Cabo Verde and, consequently, poorly understood in the archipelago. So far, a single molecular study has been carried out in Cabo Verde, which reported circulation of the L1014S mutation in local An. arabiensis [13].

The historical use of insecticides to control malaria in Cabo Verde reveals the necessity of finding molecular markers that may aid the detection and management of insecticide resistance in An. arabiensis. Thus, the present study aimed to investigate the circulation of the L1014F and L1014S alleles, often associated with resistance to pyrethroids, in natural An. arabiensis populations collected from Santiago Island, in Cabo Verde.

Cabo Verde is an archipelago of volcanic origin, composed of ten islands, located approximately $450 \mathrm{~km}$ off the West African coast, at the height of Senegal. The archipelago is characterized by its dry tropical climate and is inhabited by approximately 500,000 people $[14,37]$. Approximately $60 \%$ of the entire population resides on the largest island of the archipelago, Santiago $\left(991 \mathrm{~km}^{2}\right)$, on which the capital city of Praia is located (Fig. 1) [38, 39]. This study was carried out in two neighborhoods of Praia: Achada Grande Trás (AGT; $23^{\circ} 29^{\prime} 12.22^{\prime \prime} \mathrm{W}, \quad 14^{\circ} 55^{\prime} 11.85^{\prime \prime} \mathrm{N}$ ) and Várzea $\left(23^{\circ} 30^{\prime} 44.32^{\prime \prime} \mathrm{W}, 14^{\circ} 55^{\prime} 1.27^{\prime \prime} \mathrm{N}\right)$ (Fig. 1). The city of Praia is located on the southern coast of Santiago Island and is the economic and cultural center of Cabo Verde. Geographically, Praia may be described as a set of plateaus and respective surrounding valleys [40].

Anopheles larvae were collected in May and October 2017 (a single collection was carried out per month) in natural mosquito breeding sites, using an adapted 1-pint dipper. After each collection, larvae were sent to the insectary of the Entomology Department of Jean Piaget University of Cabo Verde and reared until the adult stage, under standard laboratory conditions $\left(25-30{ }^{\circ} \mathrm{C}\right.$, $65-75 \%$ relative humidity and a 12:12-h light:dark cycle) $[26,41]$. These specimens were then identified by classical taxonomy using the identification key of Ribeiro et al. [10]. Only mosquitoes from the An. gambiae complex were used for subsequent molecular analysis. Following

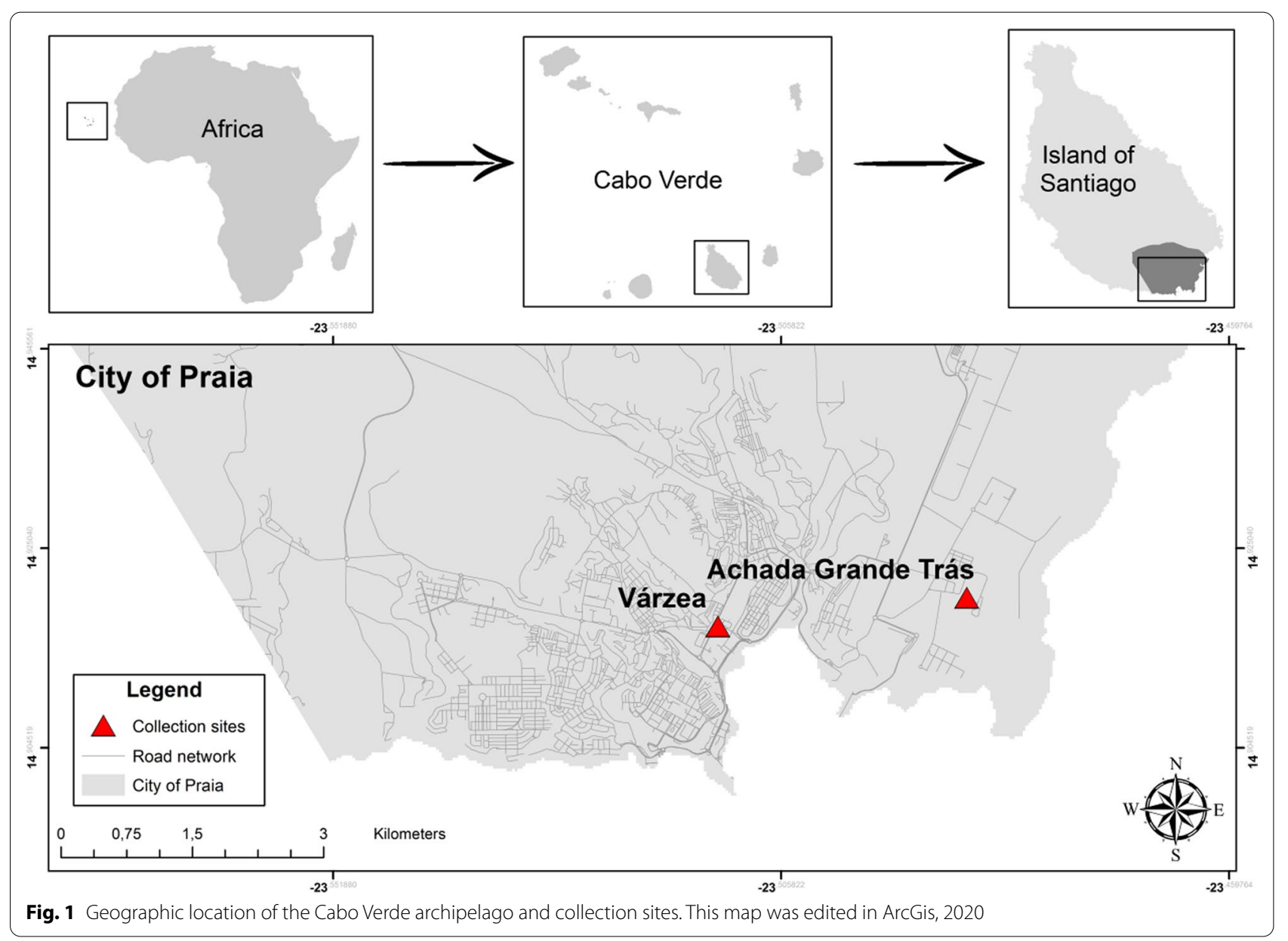


morphological identification, these mosquitoes were preserved in 70\% ethanol until DNA extraction and sent to the Entomology Department of the Aggeu Magalhães Institute (FIOCRUZ-PE) for molecular analysis.

Genomic DNA from individual mosquitoes was extracted following the protocol described by Ayres et al. [42] and the extracted DNA then stored at $-20^{\circ} \mathrm{C}$ until analysis. Molecular identification of species was performed by PCR, according to the protocol described by Scott et al. [43]. DNA samples from An. gambiae sensu s.s., kindly provided by Dr. Maria Helena Silva Filha (Entomology Department at FIOCRUZ-PE), were included in each reaction as positive controls. After species identification, DNA samples were screened for the L1014F and L1014S $k d r$ mutations, using a PCR protocol described by da Cruz et al. [13].

PCR products were sequenced using both forward/ reverse primers at the Nucleus of Technology Platforms (NPT) of the FIOCRUZ-PE, using the Sanger method (Thermo Fisher Scientific ABI 3500xL genetic analyzer system; Applied Biosystems, Foster City, CA, USA). The CodonCode Aligner program (version 3.7.1) was used to check the quality of both sequences, as well as to edit and assemble the contigs (assembly criteria: sequences with $\geq 20$ quality score were used to generate consensus sequences, based on the PHRED program). Sequence alignment and mutation identification were performed using the BioEdit program (version 7.2.6) [44].

A total of 105 Anopheles specimens belonging to the An. gambiae complex were identified by classical taxonomy and submitted for molecular species identification. The molecular analysis identified all individuals so analyzed as An. arabiensis, and these specimens were used to screen for $k d r$ mutations. Of these 105 individuals submitted for $k d r$-east/kdr-west genotyping and sequencing, 91 resulted in informative sequences. Based on the sequences of these 91 mosquitoes, 10 were determined to be heterozygous (RS) and four homozygous (RR) for the $k d r$-east mutation (L1014S); 15 were heterozygous (RS) and 10 homozygous (RR) for the $k d r$-west mutation (L1014F); the remaining mosquitoes $(n=52)$ were homozygous for the susceptible genotype (SS) (Table 1).
The L1014S and L1014F allele frequencies were 0.10 and 0.19 , respectively (Table 1 ). Although the two alleles were found in both collection areas, the L1014S allele was found more frequently in individual specimens collected in AGT, while the L1014F allele was found more frequently in those collected in Várzea (Fig. 2).

The surveillance of alleles associated with insecticide resistance in An. arabiensis populations is more frequent in other African countries than in Cabo Verde. However, Cabo Verde does not carry out surveillance in the same way as other African countries [45]. This study provides an update on the presence and frequency of $k d r$ alleles in natural populations of An. arabiensis in Cabo Verde.

Our results demonstrate, for the first time, the presence of the $1014 \mathrm{~F}$ allele in the An. arabiensis population from Cabo Verde. Although the sampling periods and localities differ from those in the study of da Cruz et al. [13], our data also show that the frequency of the $1014 \mathrm{~S}$ allele (kdr-east) has increased, from 0.073 in da Cruz et al. [13] in samples collected in Cabo Verde in 2015, to 0.10 (present study). This difference shows that this allele is being gradually selected.

The $k d r$-west and $k d r$-east mutations have been found in several countries of the African continent, such as Burkina Faso, Côte d'Ivoire, Togo, Tanzania, Kenya, Senegal, Uganda, Ethiopia and Democratic Republic of Congo [24, $28,30,32,33,46-52]$. This distribution indicates a dissemination of these two alleles across the continent as a consequence of gene flow between the different Anopheles populations and biogeographic regions [53].

In the present study, both mutations were found in the two study locations (AGT and Várzea), indicating that these mutations may be well distributed in Praia, where vector control based on chemical compounds is more frequent. However, a broader collection must be performed in other neighborhoods in the city of Praia to better estimate the allele frequency and their geographical distribution. As mentioned by da Cruz et al. [13], it is possible that the high frequency of alleles is associated with frequent use of pyrethroids in certain locations. More recently, temephos resistance was reported in An. arabiensis from the city of Praia

Table 1 L1014S/L1014F genotype and allele frequency from Anopheles arabiensis collected in Praia City, Cabo Verde

\begin{tabular}{|c|c|c|c|c|c|c|c|c|c|}
\hline \multirow[t]{2}{*}{ Localities } & \multirow[t]{2}{*}{$n$} & \multirow{2}{*}{$\begin{array}{l}\text { Susceptible } \\
\text { genotype } \\
\text { SS }\end{array}$} & \multirow{2}{*}{$\begin{array}{l}\text { Allelic frequency } \\
\text { S }\end{array}$} & \multicolumn{2}{|c|}{ L1014S genotypes } & \multirow{2}{*}{$\begin{array}{l}\text { Allelic frequency } \\
\text { R }\end{array}$} & \multicolumn{2}{|c|}{ L1014F genotypes } & \multirow{2}{*}{$\begin{array}{l}\text { Allelic frequency } \\
\text { R }\end{array}$} \\
\hline & & & & $\mathrm{RR}$ & RS & & $\mathrm{RR}$ & RS & \\
\hline Várzea & 26 & 17 & 0.69 & 1 & 1 & 0.06 & 6 & 1 & 0.25 \\
\hline AGT & 65 & 35 & 0.71 & 3 & 9 & 0.12 & 4 & 14 & 0.17 \\
\hline Total & 91 & 52 & 0.71 & 4 & 10 & 0.10 & 10 & 15 & 0.19 \\
\hline
\end{tabular}

AGT Achada Grande Trás, $N$ number of Anopheles arabiensis analyzed, $R$ resistant allele, $S$ susceptible wild-type allele, $R R$ homozygous individuals for L1014F/S mutations, $R S$ heterozygous individuals, $S S$ susceptible homozygous individuals 


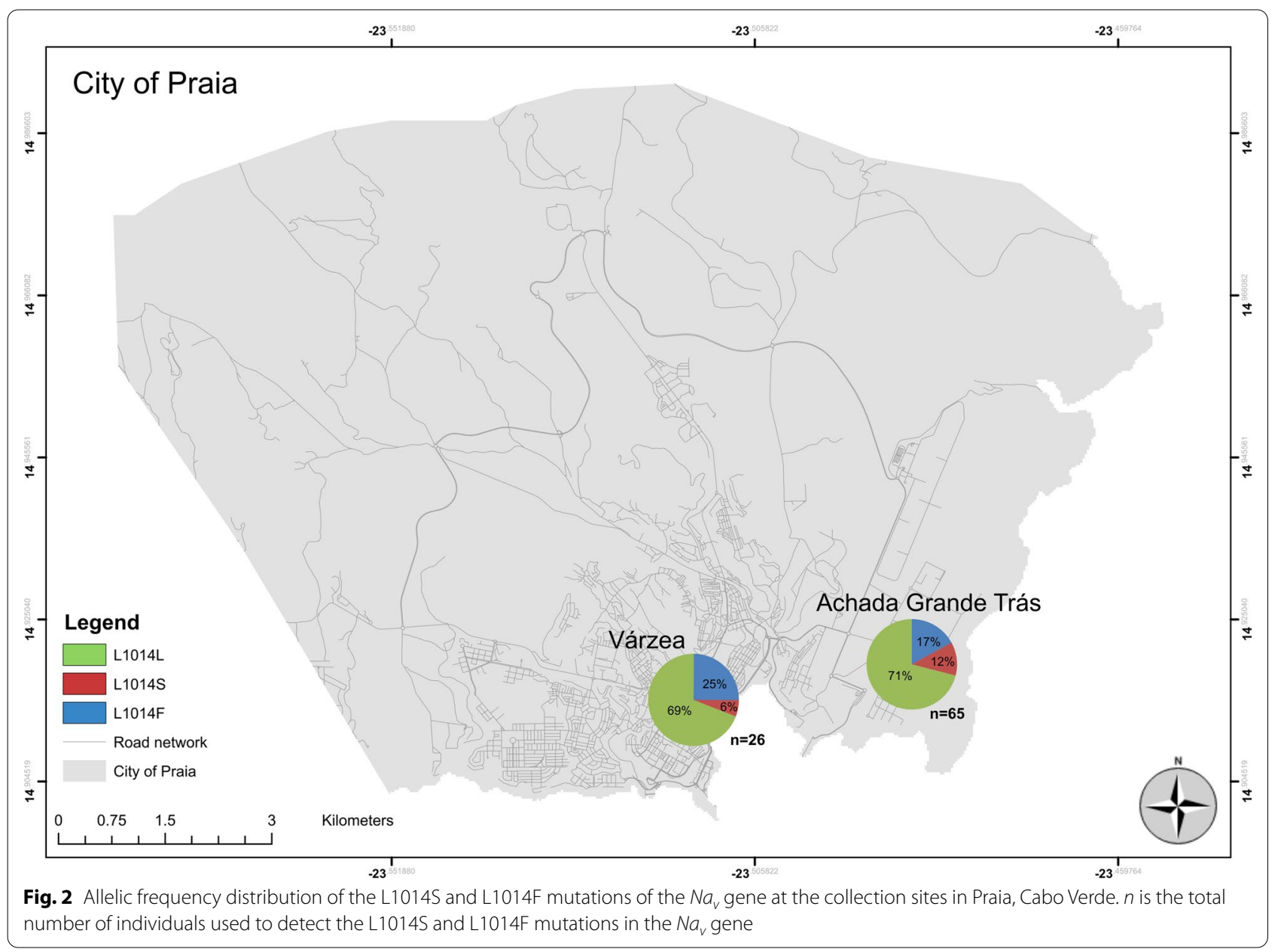

[54], collected at the same time and at the same locations, which suggest a possible selective pressure for resistance to insecticides due to their greater use (frequency and quantity). Unfortunately, there is currently no public data on the use of pyrethroids by location to allow any estimation of a possible association between the use of chemical compounds on the island and the reported resistance data.

It is important to note that this is the second study related to mutations associated with molecular resistance in An. arabiensis carried out in Cabo Verde. These $k d r$ mutations found in our study may be responsible for the resistance to deltamethrin $0.05 \%$ reported by DePina et al. [55] in the An. arabiensis population from the city of Praia. Those samples were collected during the same period that our samples were collected. The results suggest that the vector is adapting to the insecticides used in the local vector control program. The presence of these mutations represent a threat to vector control in Cabo Verde, since LLINs, a measure recently implemented by the Ministry of Health, contain deltamethrin, which could contribute to an increase in resistance to pyrethroids in the wild Anopheles population.

The results found in this study emphasize the need for frequent monitoring of the anopheline's susceptibility to insecticides used in the vector control program in Cabo Verde. The WHO [23] recommends periodical monitoring of insecticide resistance in vector populations and that the monitoring process of insecticide resistance in malaria vector mosquitoes includes tests to determine the phenotype frequency (e.g. bioassays) and the mechanisms of resistance (e.g. molecular tests that determine the allele and genotype frequency). Unfortunately, in this study, it was not possible to perform bioassays to determine the phenotype of resistance to pyrethroids; therefore, we strongly recommend that in future studies, phenotypic analysis be performed followed by the determination of molecular mechanisms of resistance.

This study revealed an increase in the frequency of the $k d r 1014 \mathrm{~S}$ allele, when compared with previous findings, as well the presence of the $k d r 1014 \mathrm{~F}$ allele (identified for the first time) in An. arabiensis 
individuals collected on the island of Santiago. These results highlight the urgent need to create new vector surveillance strategies to establish new approaches in the vector control program in Cabo Verde. Molecular monitoring of resistance to chemical insecticides should continue to be carried out in order to guide the competent authorities in making decisions, such as the implementation of novel insecticides in the malaria vector control program in Cabo Verde.

\begin{abstract}
Abbreviations
AGT: Achada Grande Trás; IRS: Indoor residual spraying; kdr: Knockdown resistance; LLINs: Long-lasting insecticide nets; $\mathrm{Na}_{v}$ : Voltage-gated sodium channel; RR: Homozygous individuals for L1014F/S mutations; RS: Heterozygous individuals; SS: Homozygous individuals; WHO: World Health Organization.
\end{abstract}

\section{Acknowledgements}

The authors would like to thank the Technological Platform of Aggeu Magalhães Institute for helping with the sequencing. The GIDTPiaget group, in particular Sílvia Gonçalves Pires, is thanked for helping with mosquito collections. The authors would like to thank Rodrigo Loyo for producing the maps.

\section{Authors' contributions}

DC made substantial contributions to conception and design, or acquisition of data. DC conducted all the experiments and was a major contributor in writing the manuscript. MP, DG, EG, LG, SP and CA were involved in drafting the manuscript and revising it critically for important intellectual content. CA and MP supervised the project. All authors read and approved the final version of the manuscript.

\section{Funding}

This research was funded by Capes (Coordenação de Aperfeiçoamento de Pessoal de Nível Superior_-Brasil, Grant Number: 0021/13), Fundação de Amparo à Ciência e Tecnologia do Estado de Pernambuco (APQ-0085-2.13/16) and Fiocruz.

\section{Availability of data and materials}

All data generated or analyzed during this study are included in this published article. The DNA sequences obtained here for each mutation were submitted to GenBank with the following access codes: RR (MW577186) and RS (MW577187) for the L1014F allele; and RR (MW577183) and RS (MW577184) for the L1014S allele. For the susceptible genotype (SS) the access code is MW577185.

\section{Declarations}

Ethics approval and consent to participate

Not applicable.

\section{Consent for publication}

Not applicable.

\section{Competing interests}

The authors declare that they have no competing interests.

\section{Author details}

${ }^{1}$ Departamento de Entomologia, Instituto Aggeu Magalhães/Fundaçao Oswaldo Cruz (FIOCRUZ-PE), Av. Professor Moraes Rego s/n, Cidade Universitaria, Recife, PE 50670-420, Brazil. ${ }^{2}$ Centro Academico do Agreste, Universidade Federal de Pernambuco, Rodovia BR-104, km 59-Nova Caruaru, Caruaru, PE 55002-970, Brazil. ${ }^{3}$ Departamento de Parasitologia, Instituto Aggeu Magalhaes/Fundaçao Oswaldo Cruz (FIOCRUZ-PE), Av. Professor Moraes Rego s/n, Cidade Universitária, Recife, PE 50670-420, Brazil. ${ }^{4}$ Universidade Jean Piaget (UniPiaget), Praia, Caixa 775, Cape Verde.
Received: 5 August 2021 Accepted: 8 November 2021

Published online: 21 November 2021

\section{References}

1. World Health Organization. World malaria report 2019. Geneva. 2019. https://www.who.int/publications-detail/world-malaria-report-2019. Accessed 9 Dec 2020.

2. Luc DS, Benoit A, Laurette D, Michel M. Indirect evidence that agricultural pesticides select for insecticide resistance in the malaria vector Anopheles gambiae. J Vector Ecol. 2016;41:34-40.

3. Wiebe A, Longbottom J, Gleave K, Shearer FM, Sinka ME, Massey NC, et al. Geographical distributions of African malaria vector sibling species and evidence for insecticide resistance. Malar J. 2017;16:85-95.

4. Millar SB, Cox-Singh J. Human infections with Plasmodium knowlesizoonotic malaria. Clin Microbiol Infect. 2015;21:640-8.

5. Harbach RE. The classification of genus Anopheles (Diptera: Culicidae): a working hypothesis of phylogenetic relationships. Bull Entomol Res. 2004;94:537-53.

6. Hunt RH, Coetzee M, Fettene M. The Anopheles gambiae complex: a new species from Ethiopia. Trans R Soc Trop Med Hyg. 1998;92:231-5.

7. World Health Organization. The Africa malaria report 2003. Geneva: WHO;2003." PARA " 7. World Health Organization. The Africa malaria report 2003. Geneva:WHO;2003. https://apps.who.int/iris/handle/10665/ 67869. Acsessed 12 June 2021.

8. Coetzee M. Distribution of the African malaria vectors of the Anopheles gambiae complex. Am J Trop Med Hyg. 2004;70:103-4.

9. Kiszewski A, Mellinger A, Spielman A, Malaney P, Sachs SE, Sachs J. A global index representing the stability of malaria transmission. Am J Trop Med Hyg. 2004;70:486-98.

10. Ribeiro H, Ramos H, Capela R, Pires C. Os mosquitos de Cabo Verde (Diptera: Culicidae)—sistemática, distribuição, bioecologia e importância médica. Lisbon: Junta de Investigações Científicas do Ultramar; 1980.

11. Alves J, Roque AL, Cravo P, Valdez T, JelinekT, do Rosário VE, et al. Epidemiological characterization of Plasmodium falciparum in the Republic of Cabo Verde: implications for potential large-scale re-emergence of malaria. Malar J. 2006;5:32-40.

12. Cambournac F, Petrarca V, Coluzzi M. Anopheles arabiensis in Cape Verde archipelago. Parassitologia. 1982;14:265-7.

13. da Cruz DL, Paiva MHS, Guedes DRD, Alves J, Gómez LF, Ayres CFJ. Detection of alleles associated with resistance to chemical insecticide in the malaria vector Anopheles arabiensis in Santiago. Cabo Verde Malar J. 2019;18:120-31.

14. World Health Organization. Eliminating malaria: moving towards sustainable elimination in Cape Verde. Geneva: WHO; 2012." para 14. World Health Organization. Eliminating malaria: moving towards sustainable elimination in Cape Verde. Geneva: WHO; 2012. https://apps.who.int/iris/ handle/10665/75849. Accessed 15 June 2021.

15. World Health Oranization. Cabo Verde attains zero local malaria transmission. 2021. http://www.who.int/mediacentre/factsheets/fs348/en/. Accessed 12 Oct 2021.

16. Irving $\mathrm{H}$, Wondji $\mathrm{CS}$. Investigating knockdown resistance $(k d r)$ mechanism against pyrethroids/DDT in the malaria vector Anopheles funestus across Africa. BMC Genet. 2017;18:76-87.

17. World Health Organization. Global plan for insecticide resistance management in malaria vectors. Geneva: WHO; 2012." para 17. World Health Organization. Global plan for insecticide resistance managementin malaria vectors. Geneva: WHO; 2012. https://apps.who.int/iris/handle/ 10665/44846. Accessed 20 July 2021.

18. Snow RW, Amratia P, Kabaria CW, Noor AM, Marsh K. The changing limits and incidence of malaria in Africa: 1939-2009. Adv Parasitol. 2012;78:169-262.

19. World Health Organization. World Malaria Report 2014. Geneva: WHO;2014." para 19. World Health Organization. World Malaria Report 2014. Geneva:WHO;2014. https://reliefweb.int/report/world/world-malar iareport-2014. Accessed 16 May 2021.

20. Djègbè I, Agossa FR, Jones CM, Poupardin R, Cornelie S, Akogbéto M, et al. Molecular characterization of DDT resistance in Anopheles gambiae from Benin. Parasit Vectors. 2014;7:409-18. 
21. Protopopoff N, Matowo J, Malima R, Kavishe R, Kaaya R, Wright A, et al. High level of resistance in the mosquito Anopheles gambiae to pyrethroid insecticides and reduced susceptibility to bendiocarb in north-western Tanzania. Malar J. 2013;12:149.

22. Ranson H, N'Guessan R, Lines J, Moiroux N, Nkuni Z, Corbel V. Pyrethroid resistance in African anopheline mosquitoes: what are the implications for malaria control? Trends Parasitol. 2011;27:91-8.

23. World Health Organization. Test procedures for insecticide resistance monitoring in malaria vector mosquitoes. Geneva: WHO; 2016." para 23. World Health Organization. Test procedures for insecticide resistance monitoring in malaria vector mosquitoes. Geneva:WHO; 2016. https:// apps.who.int/iris/bitstream/handle/10665/250677/9789241511575-eng. pdf. Accessed 9 June 2020.

24. Chouaïbou M, Kouadio FB, Tia E, Djogbenou L. First report of the East African kdr mutation in an Anopheles gambiae mosquito in Côte d'Ivoire. Wellcome Open Res. 2017;2:8.

25. Abdalla H, Wilding CS, Nardini L, Pignatelli P, Koekemoer LL, Ranson H, et al. Insecticide resistance in Anopheles arabiensis in Sudan: temporal trends and underlying mechanisms. Parasit Vectors. 2014;7:213-22.

26. Hakizimana E, Karema C, Munyakanage D, Iranzi G, Githure J, Tongren JE, et al. Susceptibility of Anopheles gambiae to insecticides used for malaria vector control in Rwanda. Malar J. 2016;15:582-93.

27. Martinez-Torres D, Chandre F, Williamson MS, Darriet F, Bergé JB, Devonshire $\mathrm{AL}$, et al. Molecular characterization of pyrethroid knockdown resistance $(k d r)$ in the major malaria vector Anopheles gambiae s.s. Insect Mol Biol. 1998;7:179-84.

28. Dabiré RK, Namountougou M, Diabaté A, Soma DD, Bado J, Toé HK, et al. Distribution and frequency of $k d r$ mutations within Anopheles gambiae s.l. populations and first report of the Ace.1G119S mutation in Anopheles arabiensis from Burkina Faso (West Africa). PLoS ONE. 2014;9:e101484.

29. Lynd A, Oruni A, Van't Hof AE, Morgan JC, Naego LB, Pipini D, et al. Insecticide resistance in Anopheles gambiae from the northern Democratic Republic of Congo, with extreme knockdown resistance $(k d r)$ mutation frequencies revealed by a new diagnostic assay. Malar J. 2018;17:412-20.

30. Mathias DK, Ochomo E, Atieli F, Ombok M, Bayoh MN, Olang G, et al. Spatial and temporal variation in the $k d r$ allele L1014S in Anopheles gambiae s.s and phenotypic variability in susceptibility to insecticides in Western Kenya. Malar J. 2011;10:13.

31. Kanzaa JPB, El Fahime E, Alaoui S, Essassi EM, Brooke B, Malafu AN, et al. Pyrethroid, DDT and malathion resistance in the malaria vector Anopheles gambiae from the democratic Republic of Congo. Trans R Soc Trop Med Hyg. 2013;107:8-14.

32. Djègbè I, Akoton R, Tchigossou G, Ahadji-Dabla KM, Atoyebi SM, Adéoti R, et al. First report of the presence of L1014S Knockdown-resistance mutation in Anopheles gambiae s.s. and Anopheles coluzzii from Togo, West Africa. Wellcome Open Res. 2018;3:30-44.

33. Yewhalaw D, Van Bortel W, Denis L, Coosemans M, Duchateau L, Speybroeck N. First evidence of high knockdown resistance frequency in Anopheles arabiensis (Diptera: Culicidae) from Ethiopia. Am J Trop Med Hyg. 2010;83:122-5.

34. Lucas ER, Rockett KA, Lynd A, Essandoh J, Grisales N, Kemei B, et al. A high throughput multi-locus insecticide resistance marker panel for tracking resistance emergence and spread in Anopheles gambiae. Sci Rep. 2019;9:13335.

35. Mitri C, Markianos K, Guelbeogo WM, Bischoff E, Gneme A, Eiglmeier K, et al. The kdr-bearing haplotype and susceptibility to Plasmodium falciparum in Anopheles gambiae: genetic correlation and functional testing. Malar J. 2015;14:391-402.

36. Hemming-Schroeder E, Strahl S, Yang E, Nguyen A, Lo E, Zhong D, et al. Emerging pyrethroid resistance among Anopheles arabiensis in Kenya. Am J Trop Med Hyg. 2018;98:704-9.

37. Barros E. Plano de ocupação de terreno em Cabo Verde para empreendimento turístico. Lisbon: Instituto Superior Técnico; 2011.

38. Instituto Nacional de Estatística de Cabo Verde. Projecções demográficas de Cabo Verde 2010-2030. Cape Verde: Instituto Nacional de Estatística; 2013
39. Instituto Nacional de Estatística de Cabo Verde. Apresentação de dados preliminares do IV RGPH 2010 gabinete do censo 2010. Cape Verde: Instituto Nacional de Estatística de Cabo Verde; 2010.

40. Monteiro S, Veiga É, Fernandes É, Fernandes H, Rodrigues J, Cunha L. Crescimento urbano espontâneo e riscos naturais na cidade da Praia (Cabo Verde). Cadernos de Geografia. 2012:30/31:117-30.

41. Nwane P, Etang J, Chouaïbou M, Toto JC, Koffi A, Mimpfoundi R, et al. Multiple insecticide resistance mechanisms in Anopheles gambiae s.l. populations from Cameroon, Central Africa. Parasit Vectors. 2013;6:41.

42. Ayres C, Romão T, Melo-Santos M, Furtado A. Genetic diversity in Brazilian populations of Aedes albopictus. Mem Inst Oswaldo Cruz. 2002;97:871-5.

43. Scott JA, Brogdon WG, Collins FH. Identification of single specimens of the Anopheles gambiae complex by the polymerase chain reaction. Am J Trop Med Hyg. 1993;49:520-9.

44. Hall TA. BioEdit: a user-friendly biological sequence alignment editor and analysis program for Windows 95/98/NT. Nucleic Acids Symp Ser. 1999;41:95-8.

45. World Health Organization. Global report on insecticide resistance in malaria vectors: 2010-2016. Geneva: WHO; 2018." para 45. World Health Organization. Global report on insecticide resistance in malaria vectors: 2010-2016. Geneva:WHO; 2018. https://apps.who.int/iris/handle/10665/ 272533. Accessed 10 May 2021.

46. Kwiatkowska RM, Platt N, Poupardin R, Irving H, Dabire RK, Mitchell S, et al. Dissecting the mechanisms responsible for the multiple insecticide resistance phenotype in Anopheles gambiae s.s., M form, from Vallée du Kou, Burkina Faso. Gene. 2013;519:98-106.

47. Kawada H, Futami K, Komagata O, Kasai S, Tomita T, Sonye G, et al. Distribution of a knockdown resistance mutation (L1014S) in Anopheles gambiae s.s. and Anopheles arabiensis in western and southern Kenya. PLoS ONE. 2011; 6(9):e24323 https://doi.org/10.1371/journal.pone.00243 23.

48. Verhaeghen K, Van Bortel W, Roelants P, Backeljau T, Coosemans M. Detection of the East and West African kdr mutation in Anopheles gambiae and Anopheles arabiensis from Uganda using a new assay based on FRET/Melt Curve analysis. Malar J. 2006;5:16.

49. Badolo A, Traore A, Jones CM, Sanou A, Flood L, Guelbeogo WM, et al. Three years of insecticide resistance monitoring in Anopheles gambiae in Burkina Faso: resistance on the rise? Malar J. 2012;11:232-43.

50. Kabula B, Kisinza W, Tungu P, Ndege C, Batengana B, Kollo D, et al. Cooccurrence and distribution of East (L1014S) and West (L1014F) African knock-down resistance in Anopheles gambiae sensu lato population of Tanzania. Trop Med Int Heal. 2014;19:331-41.

51. Ochomo E, Subramaniam K, Kemei B, Rippon E, Bayoh NM, Kamau L, et al. Presence of the knockdown resistance mutation, Vgsc-1014F in Anopheles gambiae and An. arabiensis in western Kenya. Parasit Vectors. 2015;8:616.

52. Thiaw O, Doucouré S, Sougoufara S, Bouganali C, Konaté L, Diagne N, et al. Investigating insecticide resistance and knock-down resistance $(k d r)$ mutation in Dielmo, Senegal, an area under long lasting insecticidaltreated nets universal coverage for 10 years. Malar J. 2018;17:123-32.

53. Ndiath MO, Cailleau A, Orlandi-Pradines E, Bessell P, Pagès F, Trape JF, et al. Emerging knock-down resistance in Anopheles arabiensis populations of Dakar, Senegal: first evidence of a high prevalence of $k d r$-e mutation in West African urban area. Malar J. 2015;14:364-73.

54. Pires S, Alves J, Dia I, Gómez LF. Susceptibility of mosquito vectors of the city of Praia, Cabo Verde, to Temephos and Bacillus thuringiensis var israelensis. PLOS ONE. 2020;15:e0234242.

55. DePina AJ, Namountougou M, Leal SV, Varela IBF, Monteiro DDS, de Sousa CMR, et al. Anopheles gambiae sensu lato susceptibility to the insecticides in Praia, Cape Verde: a country in the pre-elimination of malaria. Vector Biol J Res. 2018;3:5.

\section{Publisher's Note}

Springer Nature remains neutral with regard to jurisdictional claims in published maps and institutional affiliations. 